the week without much hope for a moratorium. Although it thinks that the whaling nations are "nervous" of public opinion, it admits that there is a "lack of enthusiasm" for the moratorium. The biggest danger is that if the proposal is carried with the necessary two thirds majority, the Soviet Union and Japan may leave the IWC. So the best hope is that the conference will be able to tighten up on quotas and possibly agree on a moratorium on certain species.

\section{NUCLEAR WEAPONS}

\section{Frunce Presses on}

In spite of protests from all around the world and, even more uncharacteristically, from within France itself, the French government announced earlier this week that it will carry on with its planned atmospheric nuclear tests in the South Pacific. The French Defence Ministry announced on Sunday that the delay in beginning the tests since the warning to shipping to steer clear of the area was issued five days earlier was due solely to unfavourable weather. Thus were dashed the speculations at the weekend that France would back down, as it did last year, when that series of tests ended prematurely after protests from Peru.

The renewed threat by Peru to sever diplomatic relations with France will not cut much ice this time. Opinion in London is that France is now less worried about the possible loss of sales of military equipment to South America. In the past five years, France has sold Mirage fighter bombers to five Central American and South American countries, Peru included.

Opposition to the tests rests chiefly on the inevitable spread of fallout from atmospheric tests. France tested some weapons underground in the Sahara as long ago as 1962, but the costs are now higher and the Sahara is no longer available.

What are the new tests likely to accomplish? First, the French have still to develop a usable fusion warhead for their weapons, the eighteen landbased missiles and the several submarine rockets fitted with either fission or "doped fusion" warheads. The problem that the French are out to solve is how to develop a trigger for a fusion weapon.

It is also likely that the new tests are meant to perfect the miniaturization of fission nuclear warheads for France's Pluton weapons - mobile tactical weapons with a range of up to 75 miles. It was originally planned to have these weapons in service in 1972 but this date has gradually slipped, partly because of lack of money but also because of technical difficulties. The yield of one of these weapons will be of the order of 20 kilotons.

Some support for the French claim that their tests do not produce significant radioactivity is given in a recent report from the New Zealand Department of Health (Fallout from Nuclear Weapons Tests Conducted by France in the South Pacific from June to August 1971, NRL-F/47). The New Zealand authorities have been monitoring the French tests since 1966 and the present report is concerned with the short lived activity, in particular the levels of iodine-131 which has a half life of 8 days. This fission fragment is a good guide to the strength and frequency of the tests.

Iodine was monitored both in milk and in cattle thyroid during the tests. The conclusions are that during the period of the tests, the average level of iodine in milk was twice that during the rest of the year, but this is insignificant compared with the limits suggested by the International Commission on Radiological Protection. For iodine in milk, the upper limit set in New Zealand is 200 picocuries per litre of milk which is less than one third the level approved by the ICRP; but the highest value recorded during the 1971 series of tests was 23 picocuries per litre with the average value countrywide being only 2 picocuries per litre. The average level when no tests were being conducted was 1 picocurie.

As expected, however, the levels of radioactivity found in Samoa, Tonga and Fiji, which are nearer the site of the French tests, are higher. During 1971, the highest levels were recorded at Apia in Samoa, with 47 picocuries per litre of milk during the test period.

In view of the short half life of iodine-131 and the fact that the prevailing winds at the French test site are westerly, thus blowing most of the radioactivity away from New Zealand, a better measure of the long term effects of the test is the strontium-90 and caesium-137 levels. The latest figures available from the New Zealand Department of Health give an average strontium-90 concentration for the twelve months ending in March 1971 of 6.5 picocuries of strontium per $g$ of calcium in milk and a level of caesium137 of 24 picocuries per $g$ of potassium in milk. These figures are, respectively, 2.5 per cent and 0.3 per cent of the reference concentration levels.

\section{EUROPEAN SCIENCE}

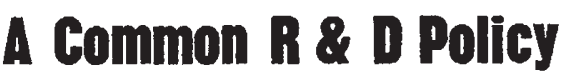

The European Commission has now produced concrete proposals for a European research and development policy (see Nature, 237, 202 and 362; 1972). The hope is that the coming enlargement of the European community will make it possible to improve on the sorry history of European cooperation in technology.

The new proposals, now to be considered by the Council of Ministers, provide for

a European Research and Development Committee (ERDC), with some 20 members, to advise on policy ;

- a European Science Foundation, to be run by the heads of the leading scientific institutions in the member countries, but with its own resources to support existing international establishments and to encourage centres of excellence such as Cern ;

- regular meetings of ministers responsible for $R$ and $D$ to reach specific decisions and to advise on priorities, with a committee of senior government officials and commission representatives to review national programmes for research and development so as to align national policies more closely.

At the official level in the commission, there is great enthusiasm for cooperation. $\mathrm{Mr}$ Christopher Layton, Chef de Cabinet to $\mathrm{Mr}$ Altiero Spinelli, the commissioner responsible for industrial, scientific and technological affairs, is known to believe that work should begin on transport, computers, electronics and telecommunications. In short, the commission is hoping that the impending enlargement of the European Community will make it possible to compete effectively with United States companies such as IBM and ITT. How will this be done?

The concept of super-European companies is by no means new. The COST group consisting of the EEC countries and 13 other European nations considered the idea of a European computer some years ago, but rejected it on the grounds that the market for such a machine could not be predicted accurately enough, and because development costs were thought to be in the order of $\$ 500$ million a year over a period of about ten years. The essential novelty in the EEC's new approach is that member Governments would in future shoulder the burden of promoting coordination.

The new schemes will cost about $\$ 110$ million a year but not all of this will be new money. The Joint Research Centre at Ispra will still consume 40 per cent of the total, even though the staff is to be reduced to 1,600 and the three reactors shut down. The European Science Foundation is reckoned to cost only 0.5 per cent of the total budget. 